\title{
Kesesuaian Lethal Autonomous Weapon Systems dengan Rezim Kontrol Persenjataan Internasional
}

\author{
Muhammad Irsan Efendi Nasution \\ Universitas Padjadjaran, Indonesia; emial: mirsan16001@ mail.unpad.ac.id \\ Hasan Sidik \\ Universitas Padjadjaran, Indonesia; email: hasan.sidik@unpad.ac.id
}

Dikirim:

6 Januari 2020
Direvisi:

25 Januari 2020
Diterima:

28 Januari 2020
Dipublikasikan:

31 Januari 2020

\section{Keywords}

Arm Dynamics,

International Humanitarian Law,

Lethal Autonomous Weapon Systems
Kata Kunci

Dinamika Persenjataan,

Hukum Humaniter Internasional,

Lethal Autonomous Weapon Systems

\begin{abstract}
In October 2001, drones from the United States with autonomous capabilities were first put into operation which then began discussions on the use of autonomous weapons on the battlefield - lethal autonomous weapon systems. In the past decade, the quantity and quality of autonomous weapons has increased. In line with intense discussions of regulatory developments. Autonomous technology has not been clearly regulated in international arms control regimes that make the legality and ethics of it remain unclear. To contribute to the discussion regarding the suitability of autonomous weapons technology with international arms control regimes, this paper will analyze the suitability of weapons systems related to using the Convention on Conventional Weapon as a body to study renewable weapons. This is done by identifying the suitability of autonomous weapons with international humanitarian law, the Martens Clause, and the ethical implications of the use of weapons. This paper then suggests that human control in the use of weapons must be the main aspect that is regulated and see no need for new laws that must be formed in regulating lethal autonomous weapon systems.
\end{abstract}

\begin{abstract}
ABSTRAK
Pada Oktober 2001, drone dari Amerika Serikat dengan kemampuan otonom pertama kali dioperasikan yang kemudian memulai diskusi penggunaan senjata otonom di medan perang - lethal autonomous weapon systems. Dalam satu dekade terakhir, kuantitas dan kualitas dari senjata otonom meningkat. Sejalan dengan diskusi perkembangan regulasi yang intens. Teknologi otonom belum diregulasi secara jelas dalam rezim kontrol persenjataan internasional yang menjadikan legalitas dan etika penggunaannya tidak jelas. Untuk berkontribusi dalam diskusi terkait kesesuaian teknologi senjata otonom dengan rezim kontrol persenjataan internasional, tulisan ini akan menganalisa kesesuaian sistem senjata terkait degan menggunakan wadah Convention on Conventional Weapon
\end{abstract}


sebagai badan untuk mengkaji senjata terbarukan. Hal ini dilakukan dengan mengidentifikasi kesesuian senjata otonom dengan hukum humaniter internasional, Klausa Martens, dan implikasi etika penggunaan senjata. Tulisan ini kemudian menyarankan agar kontrol manusia dalam penggunaan senjata harus menjadi aspek utama yang diregulasi dan melihat tidak perlu adanya hukum baru yang harus dibentuk dalam meregulasi lethal autonomous weapon systems.

\section{PENDAHULUAN}

Alat perang berubah seiring waktu. Perkembangan teknologi memainkan peran penting dalam pelaksanaan perang dan secara simultan mempengaruhi politik internasional. Perkembangan teknologi persenjataan telah sampai pada titik yang mana senjata dapat menentukan dan mengeksekusi targetnya sendiri - dirujuk sebagai Lethal Autonomous Weapon Systems. Sampai saat ini, definisi Lethal Autonomous Weapon Systems masih menjadi perdebatan, Palang Merah Internasional mengeluarkan definisi yang kemudian paing sering dirujuk:

Any weapon systems with autonomy in its critical functions. That is, a weapon systems that can select (i.e. search for or detect, identify, tract, select) and attack (i.e. use force against, neutralize, damage or destroy) targets without human interventions (International Committee of the Red Cross, 2016).

Titik fokus dari definisi ini adalah kapabilitas sistem senjata dalam membunuh target tanpa adanya intervensi manusia (Scharre \& Horowitz, 2015).

Jenis-jenis senjata otonom sendiri terbagi atas dua, yaitu automatic defense system dan autonomous offensive system. Beberapa contoh senjata otonom dengan kemampuan pertahanan adalah sistem CIWS dengan dipandu radar yang digunakan untuk mempertahankan kapal yang telah digunakan sejak tahun 1970-an. Sistem seperti itu dapat mengidentifikasi dan menyerang rudal, roket, tembakan artileri, pesawat terbang, dan kapal permukaan yang akan datang sesuai dengan kriteria yang ditetapkan oleh operator manusia. Sistem serupa ada untuk tank, seperti Arena
Rusia, Trofi Israel, dan AMAP-ADS Jerman. Beberapa jenis senjata penjaga stasioner, yang dapat menembaki manusia dan kendaraan, digunakan di Korea Selatan dan Israel. Banyak sistem pertahanan rudal, seperti Iron Dome, juga memiliki kemampuan penargetan otonom. Menara otomatis yang dipasang pada kendaraan militer disebut stasiun senjata jarak jauh.

\section{Gambar 1. Kashtan CIWS}

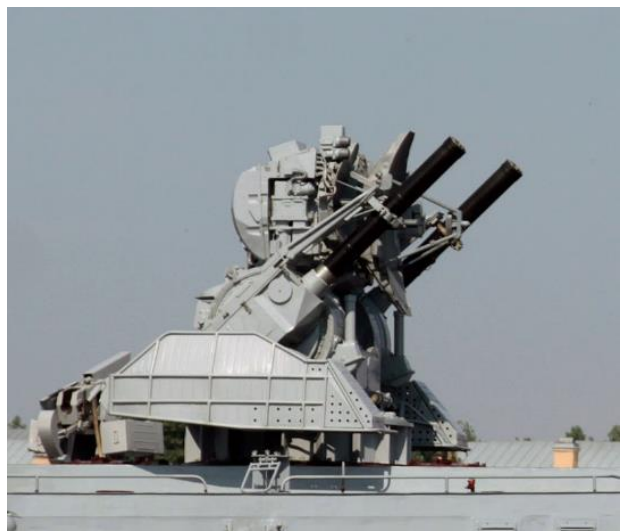

Sumber: The Naval Institute guide to world naval weapon systems

Gambar 2. Iron Dome

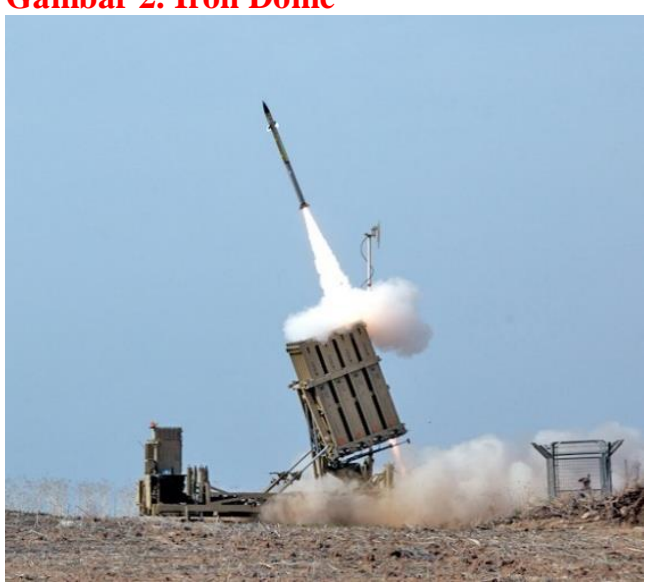

sumber: Congressional Research Service 
Sedangkan senjata otonomi ofensif memiliki sistem dengan tingkat otonomi yang lebih tinggi. Beberapa bentuk sistem senjata ini mencakup rudal dengan artifisial cerdas, drone, kendaraan tak berawak, dan robot militer. Misalnya, Modular Advanced Armed Robotic System berupa senjata darat tanpa awak yang digunakan untuk mengintai, pengawasan, dan untuk menetralisir target.

Gambar 3. The Modular Advanced Armed Robotic System

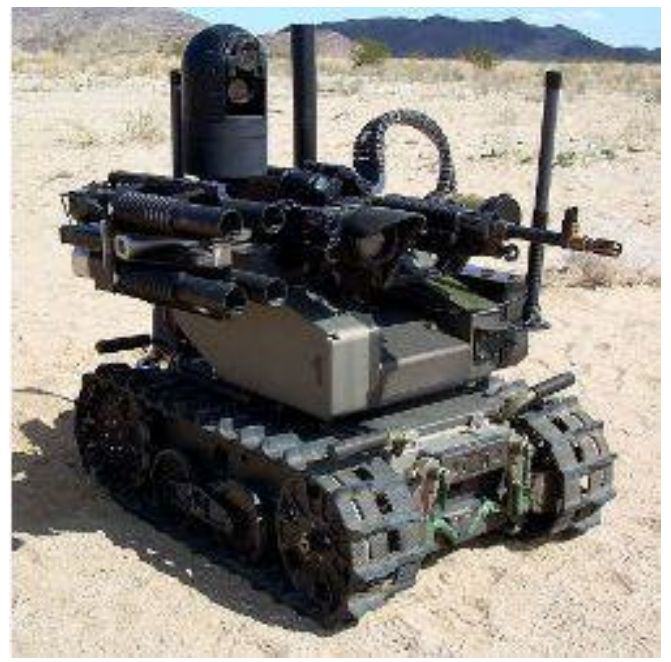

Sumber: Qinetiq North America

Gambar 4. BAE Systems Corax

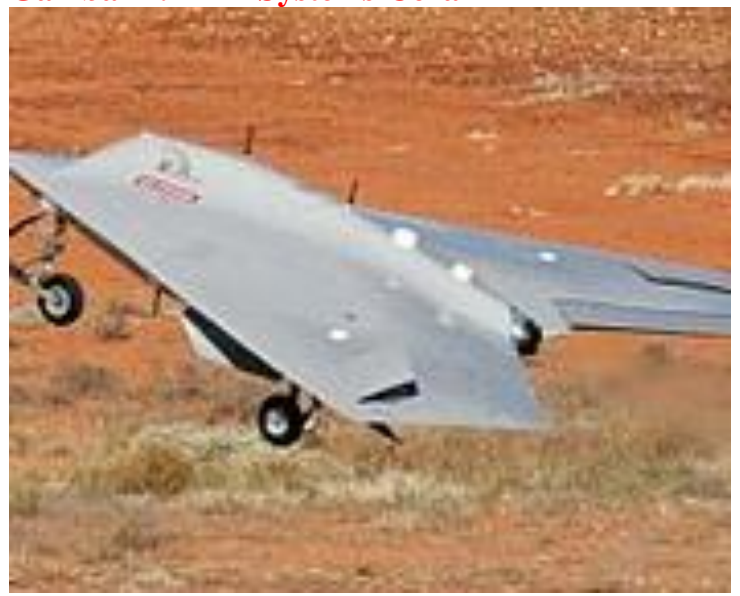

Sumber: BBC News

Penggunaan Lethal Autonomous Weapon Systems sendiri pertama kali pada 2001, berupa drone (kendaraan udara tak berawak) bernama American MQ-1, tail fin \#3034. Setelah penggunaaannya, senjata otonom menjadi topik perdebatan dalam aspek penggunaannya di medan perang. Dalam satu dekade terakhir, kuantitas dan kualitas dari Lethal Autonomous Weapon Systems meningkat. Dinamika persenjataan ini menjadikan penggunaan senjata otonom dalam medan perang akan sangat memungkinkan dalam waktu dekat.

Dari segi pengembangan, Negara-Negara seperti Amerika Serikat, Rusia, dan Israel menjadi deretan negara dalam garis terdepan. Amerika Serikat merilis Offensive SwarmEnabled Tactis (OFFSET) melalui Defense Advanced Research Projects Agency (DARPA) yang secara spesifik membahas pengembangan artificial intelligence dalam militer. DARPA juga memiliki badan dengan nama ATLAS (The Advanced Targeting and Lethality Automated Systems) yang mengembangkan dan meneliti penggunaan Lethal Autonomous Weapon Systems dalam medan perang (Bubnicki, 2005). Rusia sendiri memiliki badan riset terkait pengembangan teknologi artificial intelligence dalam militer bernama The Foundation for Advanced Research Projects yang membuka National Center for the Development of Technology and Basic Elements of Robotics di tahun 2015. Di lain pihak, strategi nasional Israel, Israeli Defense Forces dalam bagian $\mathrm{C} 4 \mathrm{i}$, telah mengembangangkan Harpy Laoitering Munition $^{1}$ yang digunakan untuk memantau perbatasan Israel-Palestina (Adisory Council of International Affairs, 2015).

Dalam menanggapi perkembangan teknologi dan aplikasi militer dari senjata otonom ini, masyarakat internasional juga memberikan resistensi. Pada tahun 2015, lebih dari 2800 ilmuwan yang bergabung dalam Future of Life Institute menandatangani surat terbuka yang ditujukan untuk pelarangan penggunaan Lethal Autonomus Weapon Systems. Ilmuwan ini termasik Stephen Hawking, Setev Wozniak, dan Elon Musk.

\footnotetext{
${ }^{1}$ an unmanned aerial vehicle that can fly around for a significant length of time to engage ground targets with an explosive warhead (Adisory Council of International Affairs, 2015)
} 
Dalam sistem internasional, regulasi tentang persenjataan menjadi salah satu isu krusial yang secara sginifikan dapat mempengaruhi dinamika persenjataan dunia. Pada 1 Oktober 2016 melalui Dewan Umum Perserikatan Bangsa-Bangsa terkait dengan Lethal Autonomous Weapon Systems, perdebatan atas legalitas Lethal Autonomous Weapon Systems terjadi, dari pertemuan ini grup pendapat pun terbentuk. Ghana, Mesir, Kuba, Ekuador, dan Pakistan menjadi deretan negara yang langsung secara terang-terangan tidak menyetujui adanya pengembangan dan pengoperasian teknologi senjata otonom.

Di lain pihak, negara-negara seperti Amerika Serikat, Israel, Republik Rakyat Tiongkok, Israel, Jepang, dan Latvia melihat pentingnya pengadaan dialog formal dan informal untuk meningkatkan pemahaman internasional terhadap senjata otonom dan menjadi wadah bagi negara-negara untuk berperan serta dalam menanggapi permasalahan-permasalahan yang muncul diakibatkan oleh Lethal Autonomous Weapon Systems. Israel sendiri melihat perlunya aspek hukum dan teknis dari Lethal Autonomous Weapon Systems dalam diskusi yang akan dilaksanakan. Jepang secara terang-terangan menyatakan tidak akan mengembangkan senjata terkait melalui working paper yang diberikannya, namun tetap mendukung keberadaan diskusi di bawah wadah yang relevan (Adisory Council of International Affairs, 2015).

Grup pendapat yang terdiri dari Finlandia, Belanda, Jerman, Irlandia, dan Polandia melihat perlunya pembentukan Group of Govermental Experts. Finlandia mengusulkan pembentukan kelompok ahli harus berada dibawah Convention on Conventional Weapon (International Committee of the Red Cross, 2019). Satu-satunya negara yang menyatakan kesetujuannya dengan pengembangan teknologi dan penggunaan sistem senjata otonom adalah Rusia.
Grafik 5. Posisi Beberapa Negara dalam pengoperasian Lethal Autonous Weapon Systems

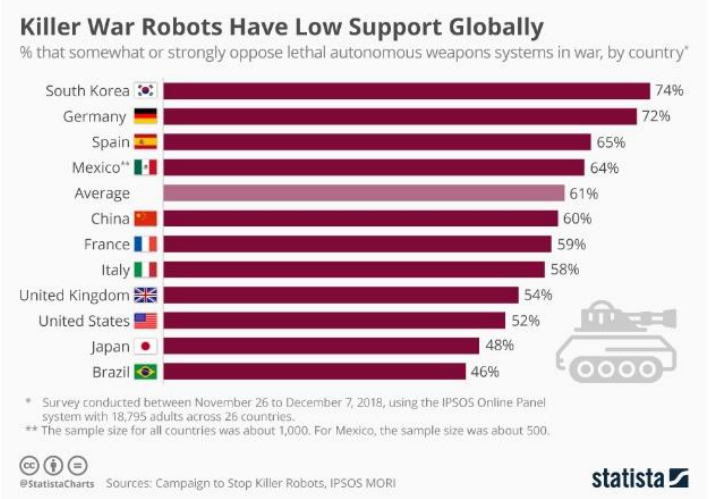

Sumber: Statista.com

Sudah menjadi hukum kebiasaan internasional bahwa suatu senjata terbaru harus dapat sejalan dengan prinsip-prinsip kemanusiaan dan hukum humaniter internasional yang dijlaskan dalam Pembukaan Konvensi Hague 1899 the application of humanity in armed conflict. Konvensi tersebut menetapkan kaidah-kaidah Jus ad Bellum, Jus in Bello - asas pembedaan (distinction) dan Jus in Bello asas proporsionalitas (proportionality). Kaidah pembeda berarti alat dan metode perang harus bisa membedakan target sesuai hukum (kombatan, obyek militer, dan masyarakat sipil yang menjadi tahanan) dan yang bukan (masyarakat sipil, obyek sipil, horse de combat, manusia, dan obyek lain yang dilindungi). Dalam Pasal 36 Protokol Tambahan I Konvensi Jenewa menyebutkan bahwa setiap negara anggota harus melaksanakan evaluasi senjata terbaru untuk memastikan efek yang dihasilkan oleh senjata tersebut dapat sejalan dengan hukum internasional (International Committee of Red Cross, 2006). Kehadiran Lethal Autonomous Weapon Systems sendiri memberikan beberapa tantangan yang harus dijawab agar dapat diterima dalam rezim perizinan persenjataan internasional, tulisan ini akan mencoba memetakan kesesuaian senjata otonom dengan rezim perizinan persenjataan internasional dengan menggunakan laporan-laporan negaranegara melalui Covention on Conventional Weapon dari metode rezim interbasional 


\section{KERANGKA KONSEPTUAL}

\section{Rezim Internasional}

Rezim dapat diartikan sebagai prinsip-prinsip, norma-norma, peraturan-peraturan, dan pengambilan keputusan yang dimana ekspektasi-ekspektasi aktor-aktor yang berperan dapat bertemu dalam area-area tertentu dalam hubungan inetrnasional. Prinsip-prinsip adalah kepercayaan terhadap fakta-fakta, penyebab, dan rectitude (Krasner, 1983). Norma-norma adalah standar dari kelakuan yang diartikan dalam istilah hak dan kewajiban. Peraturan-peraturan sendiri merupakan sebuah preskripsi dari suatu tindakan. Dan prosedur pengambilan keputusan adalah praktik yang berlaku untuk membuat dan mengimplementasikan pilihan kolektif. Salah satu tugas rezim adalah untuk memfasilitasi sebuah perjanjian.

Stephen Krasner juga mendefinisikan bahwa rezim juga mengandung variabel mediator yang eksis diantara alasan-alasan prinsip dari satu sisi dan disisi lain ada hasil dan kelakuan. Norma-norma, kriteria kelakuan dan peraturan-peraturan, perlengkapan, dan sangsi praktikal. Sehingga setidaknya ada empat pilar dari rezim: prinsip-prinsip, normanorma, peraturan-peraturan, dan prosedur pengambilan keputusan.

Bentuk-bentuk dari rezim Pertama, rezim internasional spesial dan kolektif, dimana rezim spesial berfokus pada isu spesifik dimana rezim dibentuk karenanya dan dalam kebanyakan kasus aktor-aktornya tidak bervariasi. Kedua, Laissez-Faire yang diartikan sebagai kebebasan terhadap aksiaksi. Ketiga, rezim internasional formal dan informal, dalam rezim internasional formal aktornya berupa pemerintah formal dengan memiliki statuta formal dan diadministrasikan oleh kongres dan orgaisasi resmi lainnya, dengan rezim informal kebalikannya. Keempat, rezim Imposed dan spontaneous; imposed rezim biasanya tidak memuaskan mengingat rezim ini dubuat oleh pemerintah dominan dengan bentuk hegemoni, sedangkan rezim spontaneous dibentuk tanpa adanya intervensi dan peranan pemerintah, menurut "Yung" rezim ini dientuk atas kebutuhan waktu dan tidak dibentuk oleh pemerintah atau individu yang spesifik, kelemahan dari bentuk rezim ini adalah ketidak mampuannya untuk menanggulangi masalah-masalah lingkungan. Kelima, rezim yang berdasarkan kepada kebijakan-kebijakan dan aspek-aspek strategis. Keenam, rezim internasional berdasarkan pada level isu. Ketujuh, rezim internasional regional dan global.

Rezim inetrnasional memiliki lima spesifikasi:

1. Rezim internasional menunjukkan orientasi mental.

2. Rezim memiliki prosedur yang tepat untuk pengambilan keputusan

3. Setiap rezim memiliki aktor-aktor elit dari konteks praktis.

4. Rezim mencakup prinsip-prinsip dan norma-norma yang mengklarifikasi aksi-aksi yang diperbolehkan dan yang tidak diperbolehkan.

5. Rezim dalam hubungan internasional merepresentasikan sebuah 'tingkah laku'. Bentuk tingkah laku dari internasional ini mungkin dapat didominasi oleh satu aktor, oligarki, atau komunitas sukarelawan dari peserta. Bukan suatu kewajiban dalam rezim internasional untuk mendukung keuntunan satu sama lain

Dalam riset kali ini, rezim kontrol persenjataan internasional merupakan keseluruhan hukum humaniter internasional, hukum hak asasi manusia, prinsip kemanusiaan, dan prinsip norma tentang penggunaan senjata. Dalam merespon kehadiran senjata baru seperti lethal autonomous weapon systems, rezom kontrol persenjataan internasional berlandaskan pada Pasal 36 Protokol Tambahan I Konvensi Jenewa. Otoritas yang mengatur kontrol persenjataan internasional dan kepatuhan atas aturan yang terkandung di dalam rezim merupakan Convention on Conventional 
Weapon. Convention on Conventional Weapon merupakan wadah di bawah PBB yang meninjau kelayakan senjata terbarukan. Dalam meninjau pengoperasian sistem senjata otonom sendiri, rezim kontrol persenjataan berdasar pada jus ad bellum, jus in bello, Klausa Martens, dan norma-norma yang ada.

\section{METODE RISET}

Artikel ini merupakan luaran riset skripsi yang mempergunakan metode kualitatif. Objek kajian artikel ini adalah Lethal Autonomous Weapon Systems. Sistem senjata otonom ini akan dikaji dengan menggunakan model rezim Stephen D. Krasner melalui rezim kontrol persenjataan di bawah Convetion on Conventional Weapon sebagai wadah yang mengkaji senjata terbaru. Penulis mengumpulkan data primer dan sekunder melalui studi literatur dan wawancara.

\section{HASIL DAN PEMBAHASAN}

Kerangka Hukum yang Mengatur Penerimaan Lethal Autonomous Weapon Systems dan Pengoperasiannya

Bagian ini akan membahas kerangka hukum internasional saat ini yang (kemungkinan) mengizinkan sistem senjata otonom dan batasan-batasan apa yang diberlakukan terhadap pengoperasiannya. Bagian pertama akan membahas keadaan dimana negara berhak menggunakan kekuatan dan menganalisa apakah pengoperasian dari sistem senjata otonom dapat memberikan perbedaan dalam budaya rezim penggunaan kekuatan. Bagian kedua membahas tentang rezim dan hukum internasional yang memberikan pembatasan dalam penggunaan kekuatan oleh negara (misalnya pelarangan penggunaan senjata tertentu) dan meninjau apakah sistem senjata otonom merupakan bagian dari kategori senjata terlarang. Bagian ketiga mempertimbangkan jenis-jenis target sesuai dengan hukum humaniter internasiona dan meninjau apakah lethal autonomous weapon systems dapat memberdakan antara target dan kombatan. Bagian keempat, membahas apakah pengoperasian senjata otonom dapat memenuhi persyaratan norma dan nilai-nilai kemanusiaan.

\section{Kerangka Hukum dalam Penggunaan Kekuatan oleh Negara}

Dalam tinjauan Kresner, kerangka hukum menjadi salah satu instrumen dari keseluruhan rezim. Kerangka kerja ini mencakup: Penggunaan kekerasan dalam hubungan internasional dilarang, kecuali hal-hal berikut: (1) di bawah mandat Dewan Keamanan Perserikatan Bangsa-Bangsa yang menyetujui penggunaan kekuatan untuk menjaga atau memulihkan perdamaian dan keamanan internasional; (2) pertahanan diri individu atau kolektif terhadap serangan bersenjata; atau (3) persetujuan sah dari negara bagian lain terkait penggunaan kekuatan di dalam wilayahnya. Ketiga pengecualian tersebut tunduk pada kondisi-kondisi lebih lanjut. Contohnya, hak untuk membela diri hanya dapat dilangsungkan dalam kasus serangan bersenjata yang sedang atau yang akan segera terjadi. Penggunaan kekuatan yang berdasar pada mandat Dewan Keamanan harus sejalan dengan dengan tujuan mandat Dewan Keamanan. Prinsip-prinsip keharusan membedakan target dan non-target, proporsionalitas, dan keperluan penggunaan kekuatan berlaku pada setiap penggunaan kekuatan oleh dan/atau antar negara. Dalam hal pembelaan diri, pasukan harus diperlukan untuk mengusir serangan yang sebenarnya atau yang akan terjadi serta proporsional (Advisory Council of International Affairs, 2011).

Aturan terkait penggunaan kekuatan antar negara berlaku untuk setiap penggunaan kekuatan di dalam hubungan internasional, terlepas dari jenis senjata yang akan digunakan. Oleh karena itu, aturan-aturan tadi juga berlaku pada sistem senjata yang menggabungkan tingkat automasi yang lebih besar atau lebih kecil.

Secara prinsip, sifat dari sistem senjata yang akan digunakan menjadi tidak relevan, 
ketika Dewan Keamanan PBB mengeluarkan mandat untuk mengambil semua tindakan yang diperlukan untuk melawan segala bentuk ancaman terhadap perdamaian, pelanggaran perdamaian, atau tindakan agresi. Keputusan menggunakan senjata tertentu hanya memberikan dampak legalitas pada penggunaan kekuatan dalam kasus yang tidak proporsional. Misalnya, penggunaan senjata nuklir sebagai respon terhadap serangan konvensional akan selalu dianggap tidak proporsional dan melanggar hukum.

Di lain pihak, kepemilikan dan penggunaan senjata yang dilarang atau direstriksi penggunannya di bawah rezim pengontrolan senjata (sebagai contoh senjata kimia dan/atau biologi) dianggap sebagai pelanggaran terhadap rezim kontrol persenjataan. Pada akhirnya, setiap penggunaan kekuatan tunduk pada aturan yang sama, terlepas dari jenis senjata yang digunakan.

\section{Rezim Hukum yang Mengatur} Penggunaan Kekuatan (Use of Force)

Dalam tinjauan model rezim kresner, selain berdasarkan sumber hukum, setiap penggunaan kekuatan mengharuskan entitas yang terlibat agar bertindak sejalan dengan rezim. Dasar hukum menetapkan apakah kekuatan dapat digunakan atau tidak, sementara rezim hukum menentukan dimana, bagaimana, dan terhadap siapa kekuatan dapat digunakan, serta bentuk dari kekuatan itu sendiri. Terlepas dari konvensi yang mengatur kontrol persenjataan tertentu. Ada dua rezim hukum yang meregulasi penggunaan kekuatan: rezim hukum hak asasi manusia internasional dan rezim hukum humaniter internasional

Rezim hukum humaniter internasional hanya berlaku untuk situasi konflik bersenjata dan mengatur hal-hal seperti perilaku perang. Ini termasuk penggunaan cara dan metode perang (aksi pertempuran). Hukum humaniter internasional terdiri dari sistem aturan dan prinsip yang luas dan dirancang khusus untuk mengatur situasi dimana perang dilakukan oleh otoritas yang sah dan otoritas ini memiliki kendali atas orang (baik itu kombatan maupun masyarakat sipul) dan wilayah perang

Rezim hak asasi manusia meregulasi penegakan hukum di dalam dan di luar konflik bersenjata. Rezim ini mengatur implementasi kewenangan atas orang-orang atau wilayah dengan tujuan untuk mempertahankan atau memulihkan perdamaian dan keamanan umum. Dalam penegakan hukum di situasi konflik bersenjata, maka hukum hak asasi manusia berlaku bersamaan dengan hukum humaniter internasional. Sebagai contoh pemeliharaan ketertiban umum di wilayah penduduk atau sipil. Ketiadaan konflik bersenjata menjadikan hukum hak asasi manusia menjadi satu-satunya rezim internasional yang berlaku (Gaggioli, 2013).

Secara konseptual, kedua rezim ini bekerja saling melengkapi dalam situasi-situasi dimana keduanya berlaku. Jika terjadi pertentangan di antara dua ketentuan, maka ketentuan yang lebih spesifik yang akan berlaku. Hal ini sesuai dengan prinsip lex specialis derogat legi generali. Prinsip ini tidak menyiratkan bahwa rezim lain (yang lebih generalis) dianggap sepenuhnya tidak beroperasi. Prinsip lex specialis sendiri merupakan doktrin interpretasi yang diakui secara luas untuk menyelesaikan ketidakkonsistenan antara aturan khusus dalam dua rezim hukum atau bidang hukum (Advisory Council of International Affairs, 2011).

Selain digunakan untuk mengatur konflik, kedua rezim ini juga hadir untuk membatasi. Aturan-aturan hukum humaniter internasional adalah bagian dari hukum kebiasaan internasional dan membentuk Convention on Prohibitions or Restriction on the Use of Certain Convetional Weapons Which May Be Deemed to Be Excessively Injurious or to Have Indiscriminate Effects (Convention on Conventional Weapon, CCW). Wadah ini hadir untuk mengontrol persenjataan.

Namun keberadaan konvensi-konvensi (baik yang dihasilkan oleh Convention on Conventional Weapon maupun aturan lainnya) yang mengontrol persenjataan tidak mengatur sistem senjata otonom. Ia juga tidak dapat 
termasuk ke dalam salah satu dari kategori senjata yang dilarang berdasarkan konvensikonvensi yang ada. Tentu, senjata yang tidak dilarang masih dapat digunakan tidak sejalan dengan hukum humaniter internasional. Penggunaan senjata yang menjadikannya dilarang, bukan senjata itu sendiri. Periset menekankan bahwa senjata otonom tidak secara otomatis termasuk dalam kategori senjata terlarang yang ditentukan oleh hukum humaniter internasional atau hukum dan aturan yang ada. Pertanyaan apakah sistem senjata otonom termasuk ke dalam salah satu kategori ini perlu dinilai berdasarkan kasus per kasus atau bagaimana ia dioperasikan.

\section{Lethal Autonomous Weapon Systems} dalam Prinsip-Prinsip Hukum Humaniter Internasional: Asas Pembedaan, Proporsionalitas, dan

\section{Tindak Pencegahan}

Keberadaan hukum humaniter internasional memberikan batasan-batasan tertentu dalam bagaimana konflik dilaksanakan dan pengoperasian senjata. Restriksi-restriksi ini juga berlaku seutuhnya untuk potensi pengoperasian senjata - termasuk senjata otonom. Hukum humaniter internasional tidak secara praktikal mendefinisikan bagaimana perang harus dijalankan, namun, mengatur beberapa bentuk aktivitas dengan tujuan mengatur penggunaan kekuatan dan melindungi manusia dan objek tertentu yang tidak boleh diserang. Serangan disini diartikan sebagai penggunaan kekuatan (ofensif maupun defensif) terhadap lawan, dengan maksud membunuh, melukai, atau melumpuhkan lawan (secara penuh atau sebagian) atau menghancurkan benda yang dapat dijadikan sebagai target serangan.

Argumen inilah yang sering kali digunakan sebagai pemetaan narasi bahwa Lethal Autonomous Weapon Systems tidak dapat sejalan dengan rezim perizinan persenjataan internasional (hukum humaniter internasional). Hal ini dibuktikan Misalnya pernyataan yang dikeluarkan oleh pemerintah Brazil melalui
Dewan Hak Asasi Manusia Perserikatan

Bangs-Bangsa pada 30 Mei 2017 Silam:

"In this connection, Brazil believes it worth highlighting that the development of new military technologies must carefully observe the principles of proportionality in the use of force and of distinction between civilian and military targets, as basic canons of international humanitarian law. In this context, it extends its support to the rapporteur's suggestion to convene a Human Rights Council high level panel on the use of lethal autonomous robotics for a deeper discussion on the implications of their use on human rights and on international humanitarian law" (Human Rights Council, 2013).

Pernyataan ini juga didukung oleh Mesir, dengan pernyataannya melalui Convention on Conventional Weapon, berupa:

"International attention to subject of lethal autonomous weapons has grown rapidly over the past year. Such weapons have generated widespread concern about their impacts, including with respect to distinction, proportionality, and their lack of accountability. At present there is no treaty body governing such technologies, but there is overarching rules governing this field via international humanitarian law. The need for evaluation is urgent and timely." (Campaign to Stop Killer Robots, 2013).

Dalam memetakan narasi ketidaksesuaian lethal autonomous weapon systems dengan rezim perizinan senjata internasional berdasarkan asas pembeda, periset akan mencoba untuk menjelaskan perbedaan antara target militer dengan warga sipil. Perbedaan antara target militer dan masyarakat sipil dan objek sipil terdapat dalam peraturan peperangan (regulation of hostilities). Kategori yang memenuhi syarat-syarat sebagai target militer termasuk anggota pasukan bersenjata dari pihak musuh (pengecualian pastoral dan personel medis), masyarakat sipil yang berperan langsung dalam perang secara sementara, dan anggota dari kelompok 
bersenjata terorganisir dengan fungsi tempur yang berkelanjutan. Musuh yang ditetapkan sebagai horse de combat akibat dari sakit, cedera, evakuasi darurat pesawat, karam kapal, atau penyerahan diri tidak boleh dijadikan target serangan. Orang-orang yang termasuk dalam kategori diatas harus diperlakukan secara manusiawi ketika ditangkap. Orang dan benda tertentu yang termasuk dalam kategori non-target dan hanya dapat menjadi target serangan dalam keadaan luar biasa meliputi personil medis militer dan sipil, pekerja bantuan kemanusiaan dan personel pertahanan sipil (selama tidak terlibat dalam tindakantindakan yang tidak sesuai dengan tugas medis atau kemanusiaan yang diembannya dan dapat dikategorikan berbahaya bagi musuh). Wartawan yang menjalankan tugas profesionalnya juga dilindungi, kecuali mereka berpartisipasi langsung dalam peperangan. Personel militer yang berpartisipasi dalam misi perdamaian PBB dilindungi selama mereka tidak menjadi pihak dalam konflik sesuai dengan hukum internasional.

Suatu objek dapat menjadi target sasaran militer berdasarkan lokasi, sifat, fungsi, atau penggunaannya saat sekarang atau di masa mendatang. Objek-objek yang dilindungi secara khusus termasuk properti budaya, fasilitas dan kendaraan medis, dan fasilitas dan transportasi yang krusial bagi kelangsungan hidup masyarakat sipil, misalnya pabrik pemurnian air, tanggul, dan bendungan, konvoi bantuan, dan fasilitas yang mengandung zat berbahaya (seperti pembangkit listrik tenaga nuklir), serta peralatan, fasilitas, dan kendaraan misi perdamaian Perserikatan Bangsa-Bangsa. Objek-objek diatas hanya kehilangan status perlindungan khususnya dalam keadaan luar biasa. Metode perang yang dapat menyebabkan kerusakan jangka panjang, serius, dan luas terhadap lingkungan sebagai efek samping dari menyerang sasaran militer (yang diperbolhkan sebagai sasaran) dilarang dalam hukum internasional.

Orang-orang dan benda-benda yang tidak termasuk dalam uraian sasaran militer di atas akan dikategorikan sebagai masyarakat atau benda sipil. Serangan hanya dapat diarahkan pada sasaran militer; masyarakat sipil dan benda-benda sipil tidak dapat menjadi target serangan Jika ada keraguan serius tentang status seseorang atau objek, orang atau objek maka orang atau objek tersebut tidak boleh diserang.

Prinsip pembedaan (the principle of distinction) harus dalam setiap waktu diterapkan baik dalam perencanaan maupun pelaksanaan serangan. Ini berarti bahwa serangan hanya dapat diarahkan terhadap target militer. Maka, penyerang hanya dapat menggunakan sarana (senjata) atau metode perang yang memungkinkan mereka membedakan antara target militer dan masyarkat dan objek sipil. Penyerang juga dilarang menggunakan senjata atau metode perang yang pengaruhnya tidak dapat dikendalikan.

Pernyataan itu menyiratkan bahwa serangan tidak proporsional harus dilarang. Hukum humaniter internasional mengkategorikan serangan yang tidak proporsional sebagai serangan terhadap target militer yang sekiranya akan menyebabkan hilangnya nyawa atau cedera pada warga sipil atau kerusakan pada objek sipil yang jika dibandingkan akan berlebihan dalam kaitannya dengan keuntungan militer langsung (collateral demage) dan konkret disebabkan serangan tersebut. Standar proporsionalitas ini didasarkan kepada standar seorang komandan yang mempertimbangkan bobot jaminan yang diharapkan terhadap keuntungan militer, berdasarkan informasi yang tersedia pada saat serangan dilangsungkan. Namun, ada pelarangan untuk memperlakukan daerah target militer jika hanya berisi sejumlah target militer yang berada dalam konsentrasi warga sipil dan benda-benda sipil.

Dalam melaksanakan serangan harus selalu direncanakan dan dioperasikan dengan tindakan pencegahan berkelanjutan dengan tujuan untuk melindungi masyarakat sipil dan benda sipil sebanyak mungkin dari cedera dan/atau kerusakan. Harus ada upaya besar 
dari penyerang untuk memastikan bahwa orang atau objek yang menjadi sasaran sebenarnya merupakan target militer. Serangan harus dilaksanakan sedemikian rupa sehingga kerusakan dan korban dijaga seminimal mungkin. Selain itu, penyerang harus memperingatkan masyrakat sipil sebelum serangan dilangsungkan, kecuali jika hal tersebut secara signifikan akan menggagalkan keberhasilan serangan. Serangan juga harus ditangguhkan atau dibatalkan jika cenderung menyebabkan kerusakan jaminan yang berlebihan.

Pertanyaan utama yang selalu muncul dari kelompok negara yang menyatakan ketidaksetujuannya atas Lethal Autonomous Weapon Systems adalah menyangkut kapasitas senjata otonom untuk secara mandiri memilih target yang sesuai dengan hukum humaniter internasional. Sebagian besar perdebatan mengenai pengoperasian senjata-senjata ini berfokus pada apakah pengoperasian sejata otonom dapat memenuhi asas-asas perbedaan proporsionalitas, dan tindak pencegahan.

Telah dijelaskan bahwa banyak faktor yang mempengaruhi dalam pemutusan apakah seseorang atau objek merupakan target yang sah dalam hukum internasional. Tantangan senjata otonom ini kemudian adalah membedakan kompleksitas kombatan dan masyarkat sipil, serta hubungan keduanya dalam masa perang. Senjata otonom harus dapat membedakan antara anggota yang tidak berperang dan warga sipil biasa; anggota kelompok bersenjata terorganisir dengan fungsi tempur, atau antara anggota angkatan bersenjata yang berpartisipasi dalam pertempuran dan orang-orang yang telah ditempatkan sebagai pasukan tempur yang sakit, cedera, atau menyerah; atau antara warga sipil yang berpartisipasi dalam peperangan. Belum lagi terkait standar-standar dalam asas pembedaan: partisipasi langsung dalam permusuhan (dimana harus ada 'ambang batas bahaya', 'hubungan sebabakibat antara tindakan dan kerugian', dan 'koneksi ke salah satu pihak ke pihak bersenjata konflik') atau menentukan berapa lama seseorang yang memenuhi kriteria ini terus menjadi target yang sah (International Committee of the Red Cross, 2009).

Penilaian proporsionalitas juga harus hadir dalam senjata otonom. Tidak hanya terdiri dari perkiraan kuantitatif atas jumlah yang diharapkan dari korban militer dan masyarakat sipil sebagai akibat dari pengerahan senjata tertentu, tetapi juga menyangkut penilaian apakah jumlah ini sepadan dengan keuntungan militer secara kualitatif yang diantisipasi di bawah kondisi yang berlaku. Dari pandangan grup pendapat yang tidak setuju dengan Lethal Autonomous Weapon Systems sangat tidak mungkin (setidaknya dalam ssepuluh tahun kedepan) merancang senjata otonom yang akan dapat secara mandiri menimbang keuntungan militer terhadap kerusakan jaminan, dalam kebanyakan situasi. Karena tindakan menilai keuntungan militer, dalam banyak kasus, menggunakan subyektifitas dan karena setiap penilaian sangat kontekstual dimana serangan dilakukan dan pada berbagai faktor yang mungkin dapat berubah dengan cepat. Situasi-situasi seperti ini adalah jenis situasi dimana penalaran manusia lebih dapat diandalkan daripada teknologi kecerdasan buatan.

Lethal autonomous weapon system juga harus dapat membentuk tindakan pencegahan setiap saat yang ditujukan untuk meminimalkan - dan apabila memungkinkan meniadakan - efek serangan yang berdampak pada masyarakat dan benda-benda sipil. Langkah-langkah ini termasuk verifikasi (secara berlanjut) target, pilihan senjata, waktu serangan, dan metode serangan. Serangan harus ditangguhkan jika ada keadaan yang jelas bahwa serangan akan memiliki dampak yang tidak proporsional atau jika target tidak (atau tidak lagi) sah. Jika memungkinkan, penyerang harus mengeluarkan peringatan kepada penduduk sipil sebelum serangan.

Seperti halnya semua senjata, potensi penggunaan senjata otonom tunduk pada batasan tertentu. Sebagai contoh, perlu ada 
kepastian dalam menentukan target dan di setiap serangan di daerah dimana warga sipil berada atau mungkin hadir, serangan (atau efek serangan) tidak akan memiliki dampak yang tidak proporsional pada masyarakat sipil. Demikian juga, pengoperasian senjata otonom tidak dapat dilakukan jika dampak yang dihasilkannya terhadap penduduk sipil tidak dapat diukur sebelumnya. Hal ini akan sangat berisiko pada penggunaan senjata otonom dalam situasi atau tempat yang tidak dapat diprediksi atau dapat berubah secara cepat, hal ini akan sulit untuk mematuhi persyaratan dalam hukum humaniter internasional. Saat sekarang ini, pengoperasian senjata dengan fungsi otonom hanya dikerahkan melawan wadah militer seperti pesawat militer, kapal perang, dan kendaraan militer di lingkungan atau situasi dimana tidak ada risiko kerusakan jaminan (atau dalam intensitas rendah) untuk masyarakat atau benda-benda sipil. Misalnya, Penempatan senjata defensif dengan fungsi otonom terhadap proyektil atau rudal musuh. Penggunaan sistem otonom untuk tujuan peperangan elektronik, pengintaian, navigasi, pembuangan persenjataan peledak, dan tugastugas non-mematikan lainnya juga tidak menimbulkan masalah di bidang ini. Hal yang sama berlaku untuk sistem senjata dengan otonomi tingkat tinggi dalam fungsi yang tidak mematikan.

Sifat konflik masa sekarang yang kompleks menjadikan pematuhan hukum humaniter internasional lebih sulit dilaksanakan. Sebagai contoh, konflik-konflik non-internasional dengan ketiadaan garis geografis yang jelas dan sasaran-sasaran militer terletak di wilayah yang didominasi sipil. Belum lagi intensi para kombatan yang dengan sengaja tidak membedakan diri mereka dengan masyarakat sipil menjadikan pengoperasian lethal autonomous weapon systems yang dapat sejalan dengan hukum humaniter internasional diragukan.

Dengan deskripsi diatas, agaknya pengerahan senjata otonom untuk saat sekarang (dan dalam sepuluh tahun kedepan) hanya akan diperbolehkan dalam kasus-kasus dimana ada kepastian hukum humaniter internasional tidak akan dilanggar. Dari perspektif hukum, tidak ada perbedaan antara apakah target dipilih dan dieksekusi oleh senjata otonom atau manusia; kedua kasus tersebut, dalam prosesnya, harus mematuhi hukum humaniter internasional. Bahkan jika teknologi senjata otonom sampai pada kemampuan dimana ia dapat secara mandiri menerapkan hukum humaniter internasional, persyaratan hukum yang sama akan terus berlaku untuk pengoperasiannya.

\section{Klausul Martens dalam Narasi Pelucutan Senjata}

Selain prinsip-prinsip dalam hukum kebiasaan internasional yang telah dijelaskan diatas dimana prinsip-prinsip ini hadir untuk merestriksi atau melarang jenis senjata tertentu, keraguan selanjutnya dari kelompok yang tidak setuju dengan Lethal Autonomous Weapon Systems berupa kemampuan senjata otonom agar sesuai dengan prinsip kemanusiaan. Prinsip kemanusiaan merupakan prinsip penting dalam hukum humaniter internasional dan datang dari sumber berbeda - Klausa Martens. Klausa Martens merupakan salah satu dari beberapa refleksi dari prinsip kemanusiaan yang dijelaskan pada konferensi Den Haag dan dalam Protokol Tambahan I Konvensi Jenewa yang mengkodifikasi hukum humaniter internasional (Group of Governmental Expert of Convention on Certain Conventional Weapon, 2018) yang menyatakan bahwa dalam situasi yang tidak tercakup oleh perjanjian internasional, kombatan dan masyarakat sipil tetap berada di dalam perlindungan prinsip-prinsip hukum internasional yang berasal dari kebiasaan internasional - prinsip-prinsip kemanusiaan dan dari hati nurani publik (public conscience) $)^{2}$.

\footnotetext{
${ }^{2}$ Pasal 1(2) dari Protokol Tambahan Konvensi Jenewa 12 Agustus 1949 dan hadir juga dalam Protection of Victim of International Armed Conflicts (Protocol I. 8 Juni 1977) (International Committee of the Red Cross, 2009).
} 
Pada awalnya, ketentuan ini hadir terkait dengan status masyarakat sipil bersenjata yang melawan penjajah, namun, kegunaan klausul pada saat ini merupakan sebagai pengingat bahwa dengan ketidakadaan aturan perjanjian khusus menjadikan tindakan-tindakan para pihak dalam konflik bersenjata harus tetap tunduk pada prinsip-prinsip yang ada dalam hukum humaniter internasional dan hukum kebiasaan internasional. Keseluruhan dari sistem aturan yang mengkonstruk hukum humaniter internasional menggambarkan keseimbangan antara pertimbangan kemanusiaan dan kebutuhan militer (Fleck, 2013). Meski dalam klausul ini tidak ada aturan dalam hukum kebiasaan atau aturan lainnya yang melarang penggunaan kekuatan mematikan oleh sistem senjata otonom.

Dari Laporan 2018 Group of Governmental Experts of the High Contractivng Parties to Convention on Conventional Weapon, Kepala Divisi Hukum dan Chief Legal Officer Palang Merah Internasional, Knut Dörmann, memaparkan hirauan baru dalam ulasan senjata yaitu pentingnya peran negara dalam proses nasional yang ditujukan pada persetujuan senjata dengan fungsi otonom dan memberikan gambaran tentang empat bidang tantangan untuk meninjau senjata sistem senjata otonom: (i) pemutusan kapan suatu sistem senjata memerlukan ulasan; (ii) penentuan kriteria untuk penilaian (hukum humaniter internasional, klausa Martens, hukum perjanjian, lingkungan operasi, pertimbangan etis); (iii) proses penilaian (kebanyakan tergantung pada kebijaksanaan Negara, adanya kebutuhan untuk memastikan keahlian yang memadai); (iv) dan bagaimana menghadapi ketidakpastian atau rendahnya prediktabilitas keadaan.

\section{Implikasi Moral dan Etika}

Baik hukum nasional maupun hukum internasional didasarkan pada prinsip-prinsip etika dan moral, etika dan moral memiliki cakupan lebih luas daripada hukum. Meski beberapa tindakan diperbolehkan dalam undang-undang yang ada, bukan berarti tindakan itu sesuai dalam setiap kasus - harus kontekstual. Terlebih lagi, undangan-undangan tidak menyediakan regulasi spesifik atas setiap situasi yang mungkin terjadi. Dalam kasus ini, jika ada celah dalam hukum, maka kemungkinan akan kembali pada prinsipprinsip etika dan moral yang ada untuk mencapai suatu keputusan.

Argumen yang sama digunakan oleh kelompok yang tidak setuju dengan pengembangan dan pengoperasian Lethal Autonomous Weapon Systems. Asumsi dasar yang dibawa adalah tidak etis bahwa keputusan hidup dan mati seseorang ditentukan oleh robot. Pernyataan ini dikeluarkan oleh Takhta Suci (Vatican) melalui Convention on Conventional Weapon pada 14 November 2013:

"Lethal autonomous weapons and drones, although distinct, share much the same humanitarian implications and raise several questions of grave ethical concern. Most critical is the lack of ability for pre-programmed, automated technical systems to make moral judgments over life and death, to respect human rights, and to comply with the principle of humanity. These questions will grow in relevance and urgency as robotic technology continues to develop and being utilized. With this concern in mind, I take the opportunity to express our support for your initiative, $\mathrm{Mr}$. President, that envisions the adoption of a mandate to start thinking about these important and urgent matters. Indeed advantage should be taken of all relevant contributions from all fields, particularly those of international humanitarian law and human rights law". (Convention on Conventional Weapons Meetings, 2013)

Human dignity merupakan prinsip etis yang sering kali hadir dalam perdebatan terkait sistem senjata otonom, karena ia hadir dengan membentuk landasan hukum humaniter internasional dan hak asasi manusia. Dijelaskan dalam pembukaan Piagam Perserikatan Bangsa-Bangsa, Kovenan 
Internasional tentang Hak Sipil dan Politik, dan Kovenan Internasional tentang Hak Ekonomi, Sosial, dan Budaya, dan Deklarasi Universal Hak Asasi Manusia. Instrumeninstrumen diatas mengidentifikasi human dignity sebagai sumber dari hak asasi manusia, yang juga disebutkan dalam konstitusi nasional berbagai negara. Prinsip ini juga terrefleksikan dalam hukum humaniter internasional dengan tujuan untuk menyeimbangkan keuntungan militer terhadap perlindungan martabat manusia.

Melalui laporan kepada Dewan Hak Asasi Manusia pada 9 April 2013, Profesor Christof Heyns, Special Rappourteur PBB untuk ekstrajudicial, mempertanyakan (dan meragukan) apakah human digity dilanggar ketika seseorang dibunuh oleh mesin (sistem senjata otonom). Beberapa organisasi nonpemerintah yang disatukan dalam Campaign Against Killer Robots, percaya bahwa garis moral telah dilangkahi ketika senjata otonom diizinkan untuk mengambil keputusan hidup dan mati dari seorang manusia. Heyns juga mempertanyakan apakah (secara inheren) salah membiarkan mesin otonom memutuskan siapa dan kapan untuk membunuh bahkan ketika senjata otonom dapat beroperasi dalam batas-batas hukum internasional dan terbukti menjadikan korban lebih sedikit. Jika secara inheren salah, menurutnya, tidak ada pertimbangan lain yang dapat membenarkan penyebaran dan pengembangan senjata otonom (Group of Governmental Expert of Convention on Certain Conventional Weapon, 2018). Melalui laporan yang sama, Heyns juga menekankan pentingnya moratorium dan menyarankan Komisaris Tinggi Perserikatan Bangsa-Bangsa untuk Hak Asasi Manusia untuk melaksanakan diskusi melalui panel multidisipliner yang dapat digunakan untuk melakukan inventarisasi (Group of Governmental Expert of Convention on Certain Conventional Weapon, 2018).

Terkait perdebatan etika dan senjata otonom, Profesor Ronald Arkin, College of Computing Institut Teknologi Georgia, berpendapat akan ada kemungkinan di masa depan untuk mengembangkan senjata otonom dengan kesadaran etis yang dapat berfungsi sesuai dengan standar internasional - hukum dan prinsip etika. Dalam konteks ini, 'ethical governor' yang diprogram di dalam senjata otonom dapat mencegah sistem senjata mengeksekusi target jika dimungkinkan akan mengakibatkan pelanggaran pada hukum humaniter internasional (Group of Governmental Expert of Convention on Certain Conventional Weapon, 2018). Arkin menyatakan kesetujuan bahwa senjata otonom yang diprogram secara etis tidak akan beroperasi dengan etika sempurna di medan perang, namun ia masih optimis dalam kemampuan senjata otonom yang dapat lebih etis daripada manusia (Arkin, 2012). Optimisme dalam pengembangan sensor tertentu agar senjata otonom dapat membedakan kombatan dan masyarakat sipil dalam keadaan rumit, misalnya senjata otonom tidak perlu membunuh atau melukai kombatan musuh dalam posisi pertahanan diri, masih dianggap relevan oleh kelokmpok yang setuju dengan Lethal Autonomous Weapon Systems. Senjata otonom juga tidak mengalami emosi (seperti kemarahan) dan dapat memproses lebih banyak informasi dengan kecepatan lebih cepat daripada manusia.

Gambar 6. Visual Odometry, salah satu bentuk sensor gerakan untuk Lethal Autonomous Weapon Systems

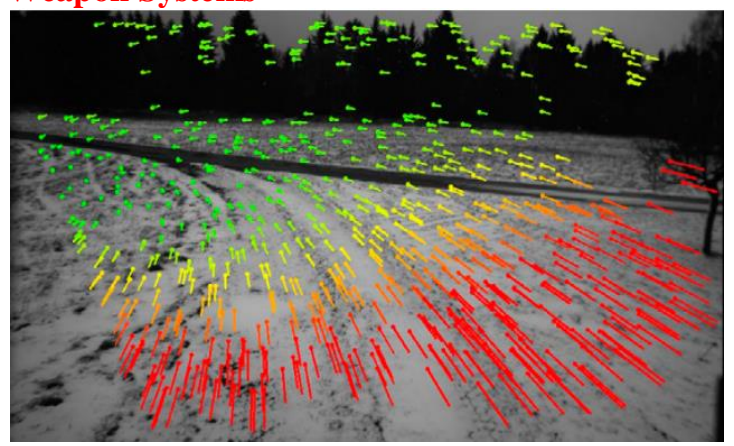

Sumber: NATO Issues for Defense Policy Maker

Periset melihat keharusan masyarakat internasional untuk mengambil keputusan secara konsensus terkait masalah etika yang berhubungan dengan sistem otonom sebelum senjata otonom dikembangkan dan 
dioperasikan secara luas. Advisory Council of International Affairs sendiri berpendapat bahwa kecelakaan atau pelanggaran atas hukum dalam medan perang tidak dapat dielakkan, misalnya dalam teknologi sipil berbasis otonom yang berkembang jauh lebih signifikan daripada teknologi otonom dalam bidang militer, kecelakaan lalu lintas yang melibatkan mobil tanpa pengemudi kemungkinan akan berakibat fatal. Pertanyaan etika yang harus dipersepsikan adalah akankah masyarakat dapat menerima bahwa mobil tanpa pengemudi (otonom) yang menyebabkan kecelakaan dan kematian, sama seperti manusia, atau mereka tidak akan diizinkan untuk melakukan kesalahan? Tindakan seperti apa yang harus diambil oleh mobil tanpa pengemudi jika semua opsi akan menimbulkan korban? Opsi-opsi berbasis etis seperti apa yang perlu diprogram ke dalam sistem? Advisory Council of International Affairs disini percaya bahwa selama pengembangan senjata otonom masih memiliki aspek kontrol manusia (meaningful human control), aspekaspek etika dan moral tidak akan memunculkan masalah serius.

\section{Kontrol Manusia yang Berarti (Meaningful Human Control)}

Meaningful human control dalam senjata memainkan peran krusial dalam perkembangan regulasi Lethal Autonomous Weapon Systems, terlepas dari kurangnya definisi dari meaningful human control yang disepakati. Dalam penggunaan kekuatan (use of force), manusia diharapkan untuk melakukan kontrol atas siapa atau apa yang diserang (baik itu orang maupun benda) dan kapan (durasi dan waktu serangan), dimana, mengapa (alasan serangan untuk seleksi atau serangan) dan bagaimana (proses serangan). Kontrol manusia berfungsi sebagai jaminan dalam hal pertimbangan etis dan untuk proses hukum dalam pengambilan keputusan penggunaan kekuatan yang berpotensi mematikan. Lebih lanjut lagi, hanya mungkin mengaitkan antara akuntabilitas dan tanggung jawab terhadap individu jika manusia (dalam hal ini operator) memiliki kendali atau kontrol atas senjata otonom. Ide dari meaningful human control memiliki implikasi terhadap tanggung jawab moral, akuntabilitas, dan kemampuan kontrol (Horowitz \& Scharre, 2015). Subbab ini ditujukan untuk berkontribusi dalam perdebatan internasional terkait keterlibatan meaningful human control dalam perkembangan regulasi Lethal Autonomous Weapon Systems.

Merujuk pada International Committee for Robot Arms Control (ICRAC), seorang komandan atau operator harus memiliki kesadaran situasional dan kontekstual secara penuh dari medan atau area target serta dapat bereaksi dan memahami setiap perubahan atau situasi tak terduga yang dapat sewaktu-waktu muncul ketika merencanakan serangan di medan perang. Selain itu, harus ada cara penangguhan atau pembatalan serangan secara tanggap (Rosert \& Sauer, 2018). Hal tersebutlah yang menjadi substansi dari meaningful human control.

Tidak semua bentuk dari kontrol manusia dapat dikategorikan bermakna (memadai atau efektif). Jika kontrol dalam hal ini hanya mengindikasikan bahwa operator dari sistem senjata otonom harus menekan tombol ketika menyala, tanpa harus menerima informasi lain, maka jelas hal ini bukan kontrol manusia yang berarti (meaningful human control). Dalam keterlibatan senjata dengan teknologi, tetap 'kesadaran situasional dan kontekstual' tadi harus hadir. Pengembang senjata Lethal Autonomous Weapon Systems berpandangan bahwa kesadaran situasional dan kontekstual tadi dapat dicapai melalui pengiriman informasi (dari sistem senjata ke operator). Hal ini tidak serta-merta menjadikan manusia (operator atau komandan) harus selalu memiliki akses ke keseluruhan informasi yang diperlukan, hal ini justru akan menghambat kinerja sistem senjata, dan mengingat realitas perang yang sulit untuk diinformasikan.

Di lapangan, meaningful human control memiliki instrumen-instrumen yang dapat 
digunakan untuk memeriksa aspek etis dan hukum dari penggunaan sistem senjata otonom, yaitu prediktabilitas (predictability) dan penilaian (judgement) (UNIDIR, 2014). Penilaian dalam hal ini merujuk pada penilaian operasi dari lethal autonomous weapon systems. Manusia (dalam hal ini penyerang) memiliki tanggung jawab untuk menilai apakah tugas memilih dan mengeksekusi target dapat diberikan kepada senjata otonom dalam konteks (spasial dan temporal) tertentu. Penilaian dapat dirancang dalam berbagai tahap selama desain dan pengadaan sistem senjata otonom serta selama proses penargetan berlangsung. Ketika komandan memutuskan untuk menggunakan sistem senjata otonom atau tidak, berarti ia akan menilai apakah ia harus memberikan kontrol langsung lebih lanjut atas fungsi kritis (yaitu pemilihan dan penyerangan target) kepada senjata otonom.

Prediktabilitas dari perilaku sistem senjata otonom sangat krusial bagi entitas yang harus memutuskan penggunaannya. Perlu adanya perilaku dari sistem senjata otonom yang dapat diprediksi/diramalkan tanpa harus secara tepat memprediksi apa yang akan terjadi. Di medan yang terdapat banyak warga sipil dan bendabenda yang dilindungi di bawah hukum humaniter internasional, ada resiko lebih besar dalam kerugian masyarakat sipil sebagai akibat sikap tidak terduga dari sistem senjata yang dioperasikan.

Periset melihat pentingnya mengadakan konsep meaningful human control sebagai konsep umum dari aspek penilaian dan prediktabilitas. Masyarakat internasional juga tampaknya setuju tentang kegunaan konsep ini sebagai landasan dalam membedakan antara jenis sistem senjata otonom yang dapat diterima dan tidak dapat diterima. Sehingga, konsep dan keberadaan meaningful human control menjadi hirauan penting.

Hukum internasional dan pertimbangan etika secara esensi hadir dengan memberikan batasa-batasan dalam penggunaan kekuatan (use of force). Manusia (penyerang baik itu operator maupun komandan) memiliki tanggung jawab untuk menghormati batasan- batasan tersebut ketika mengerahkan kekuatan melalui senjata tertentu. Meaningful human control ditujukan untuk memfasilitasi kepatuhan atas prinsip-prinsip pembedaan (distinction), proporsionalitas (proportionality), dan tindakan pencegahan (precaution). Apakah prasyarat tersebut benarbenar dipenuhi atau tidak tergantung pada entitas yang bertanggung jawab dalam memutuskan apakah akan menggunakan senjata otonom atau tidak.

\section{KESIMPULAN}

Perkembangan dan pengoperasian lethal autonomous weapon systems ditolak oleh dua puluh enam negara (termasuk Austria, Cina, Kolombia, dan Djibouti). Kelompok negara yang menolak ini beranggapan bahwa senjata otonom tidak dapat membedakan antara kombatan dan masyarakat sipil mengingat kompleksitas lingkungan perang (tidak terpenuhinya prinsip pembeda). Kemampuan senjata otonom untuk secara kontekstual menentukan tingkat proporsionalitas juga dipertanyakan. Untuk menghadirkan kontrol manusia dalam sistem senjata otonom (meaningful human control) juga menjadi tantangan, mengingat hasil observasi dari Group of Governmental Expert menyatakan bahwa akan sulit untuk mengembangkan senjata otonom dengan meaningful human control dalam sepuluh tahun kedepan.

Di lain pihak, Prancis, Israel, Rusia, Inggris, dan Amerika Serikat menyetujui pengembangan dan pengoperasian lethal autonomous weapon systems. Kelompok negara ini menitikberatkan keuntungan miiter yang ditawarkan oleh senjata otonom diantaranya kecepatan tindakan dan koordinasi, mengurangi korban tentara, dan self-sacrificing. Kemampuan sensorik (visual odementery) senjata otonom juga memainkan peran penting dalam membedakan kombatan dan masyarakat sipil di lingkungan yang kompleks, sehingga senjata otonom dapat sejalan dengan prinsip pembeda. Kelompok ini juga optimis dalam menghadirkan meaningful human control dalam sistem senjata otonom 
yang menjadikan senjata otonom dapat diprediksi dan menjadi landasan akuntabilitas.

\section{PERNYATAAN PENULIS}

Terima kasih kepada Bapak Hasan Sidik selaku pembimbing utama saya yang selalu meluangkan waktunya dalam membimbing saya menyelesaikan skripsi dan menyelesaikan penulisan jurnal ini, berkat bimbingan beliau saya mampu menyelesaikan tulisan dengan topik lethal autonomous weapon systems dan rezim kontrol persenjataan

\section{DAFTAR PUSTAKA}

Adisory Council of International Affairs. (2015). Autonomous Weapon Systems: the Need for Meaningful Human Control. Adisory Council of International Affairs.

Advisory Council of International Affairs. (2011). Cyber Warfare. Advisory Council of International Affairs.

Arkin, R. (2012). The Case for Ethical Autonomy in Unmanned System. Journal of Military Ethics.

Bubnicki, Z. (2005). Modern Control Theory. New York.

Campaign to Stop Killer Robots. (2013). Convention on Conventional Weapon Meetings of High Contracting Parties: Intervention of Egypt. Geneva: Campaign to Stop Killer Robots.

Convention on Conventional Weapons Meetings. (2013, November 14). Statement of Holy. Retrieved from Convention on Conventional Weapons Meetings of High Contracting Parties: http://www.reachingcriticalwill.org/images/ documents/Disarmament-fora/ccw/MSP2013/Statements/14Nov_HolySee.pdf.

Fleck, D. (2013). The Handbook of International Humanitarian Law. Oxford University Press.

Gaggioli, G. (2013). The Use of Force in Armed Conflict: Interplay between the Conduct of Hostilities and Law Enforcement Paradigms. ICRC Meeting Report.

Group of Governmental Expert of Convention on Certain Conventional Weapon. (2018). Report of the 2018 Session of the GGE on Emerging Technologies in the Area of Lethal Autonomous Weapon Systems. Convention on Conventional Weapon.
Horowitz, M. C., \& Scharre, P. (2015). Meaningful Human Control in Weapon Systems: A Primer, Working Paper. Center For A New American Security.

Human Rights Council. (2013, May 29). Statement of Brazil. Retrieved from Human RIghts Council: https://www.stopkillerrobots.org/wpcontent/uploads/2013/05/HRC_Brazil_09_ 30May2013.pdf

International Committee of Red Cross. (2006). A Guide to the Legal Review of New Weapons, Means and Methods of Warfare: Measures to Implement Article 36 of Additional Protocol I of 1977, 88 International Review of Red Cross 846.

International Committee of the Red Cross. (2009). Interpretative Guidance on the Notion of Direct Participation in Hostilities under International Humanitarian Law. International Committee of the Red Cross.

International Committee of the Red Cross. (2016). Autonomous Weaon System: Implications of Increasing Autonomy in the Critical Functions of Weapons.

International Committee of the Red Cross. (2019, December 04). 1980 Convention on Certain Conventional Weapons - Factsheet. Retrieved from International Committee of the Red Cross: https://www.icrc.org/en/document/1980convention-certain-conventional-weapons

Krasner, S. D. (1983). International Regime. London: Cornell University Press.

Rosert, E., \& Sauer, F. (2018). Perspectives for Regulating Lethal Autonomous Weapon at the Convention on Certain Conventional Weapon;. EISA European Workshops in International Studies, 1-32.

Scharre, P., \& Horowitz, M. C. (2015). An INtroduction to Autonomy in Weapon Systems. Center for a New American Study.

UNIDIR. (2014). The Weaponization of Increasingly Autonomous Technologies: Considering how Meaningful Human Control Might Move the Discussion Forward. UNIDIR Resources. 